\title{
Performance of composite local glass fibre sheets and epoxy on flexural strengthening of reinforced concrete beams
}

\author{
I Ketut Sudarsana ${ }^{1, *}$ \\ ${ }^{1}$ Universitas Udayana, Civil Engineering Department, Jln Kampus Udayana-Bali, Indonesia
}

\begin{abstract}
Application of fibre sheets to strengthening reinforced concrete members has been investigated extensively. This paper presents the results on the use of composite local materials such as woven roving glass fibre sheets and epoxy to flexural strengthening of reinforced concrete beams. As many as 24 specimens with variation on the number of fibre layers (one and two layers) and end anchorage techniques (fasteners, U-shape straps, steel bolts) have been tested. It is shown that the effectiveness of glass fibre can be attained only on the specimens with one-layer sheet indicated by the rupture of fibre composite before specimen failure. Strengthening using two layers, bonding failure and delamination of fibre occur before the fibre develops maximum strength. Applying end anchors on the cut-off point of the two layers of fibreglass improves performance of the composite materials in the range of $5.0 \%$ to $16.5 \%$. In addition, the end anchors also prevent delamination of the fibre sheet to occur at the cut-off point.
\end{abstract}

\section{Introduction}

Application of carbon, aramid and glass fibre reinforced polymer (CFRP, AFRP and GFRP) with epoxy bonding agent to strengthen reinforced concrete beams have been studied extensively for decades $[1,2,3,4]$. A major problem of the method is debonding of FRP from the concrete surface. Some efforts have been done to overcome debonding problems such as roughening the concrete surface [5,6] and using CFRP spike anchors [7]. These techniques can significantly improve the performance of the FRP strengthened beams. However, CFRP material is too expensive for local domestic applications since those materials are imported. There are local products of woven roving fibres glass sheet (GFRP sheet) that are usually used to build boats and canoes with local epoxy resin (®Avian) that may be used to flexural strengthen reinforced concrete beams. These composite materials between GFRP sheet and epoxy have been tested in the laboratory as concrete confinement [8] and shear strengthening of beams [9]. It was shown that those composite materials enabled to improve the specimens' capacities. The applications of woven roving GFRP sheet and local epoxy to flexural strengthen beams have been tested by $[10,11]$. This paper presents some parts of the test results in order to evaluate the

* Corresponding author: ksudarsana@unud.ac.id 
performance of local materials and three end anchorage techniques as alternative strengthening materials.

\section{Experimental program}

The experimental program was planned in two phases. The $1^{\text {st }}$ phase (Phase I) studied the effect of the layer's number and the $2^{\text {nd }}$ phase (Phase II) studied the effect of end anchors on flexural behaviour of the strengthened beams. Phase I and II were done in a different time therefore the concrete strength in each phase was different.

\subsection{Material properties}

The concrete was mixed using maximum aggregate diameter of $20 \mathrm{~mm}$ for both phases. The average concrete compressive strength in phase I was $31.99 \mathrm{MPa}$ and in phase II was $21.13 \mathrm{MPa}$.

The properties of local GFRP woven roving and epoxy used in the study were laboratory tested. It was found that the ultimate tensile strength of GFRP $\left(f_{f u}\right)$ and epoxy $\left(f_{\text {au }}\right)$ were $123.33 \mathrm{MPa}$ and $51.43 \mathrm{MPa}$, respectively, with modulus of elasticity of 5535.4 $\mathrm{MPa}$ and 20192.2 MPa.

Beam specimens were made using longitudinal and transversal reinforcement of diameter $10 \mathrm{~mm}$ and $6 \mathrm{~mm}$, respectively. The yield strength of steel reinforcement was 389 $\mathrm{MPa}$ obtained from laboratory tension test.

\subsection{Specimens}

The size of beam specimens in both phases were identical, and namely were 100x150x1100 $\mathrm{mm}$ with $2 \phi 10 \mathrm{~mm}$ for longitudinal reinforcement and $\phi 6 \mathrm{~mm}$ for stirrups with spacing of $62.5 \mathrm{~mm}$ and $45 \mathrm{~mm}$ for phase I and II, respectively. The closer stirrups spacing were used in the specimens of phase I due to incline shear cracks that occurred in the specimens of phase I. Detail specimens for phase I and II can be seen in Figure 1 and 2, respectively.
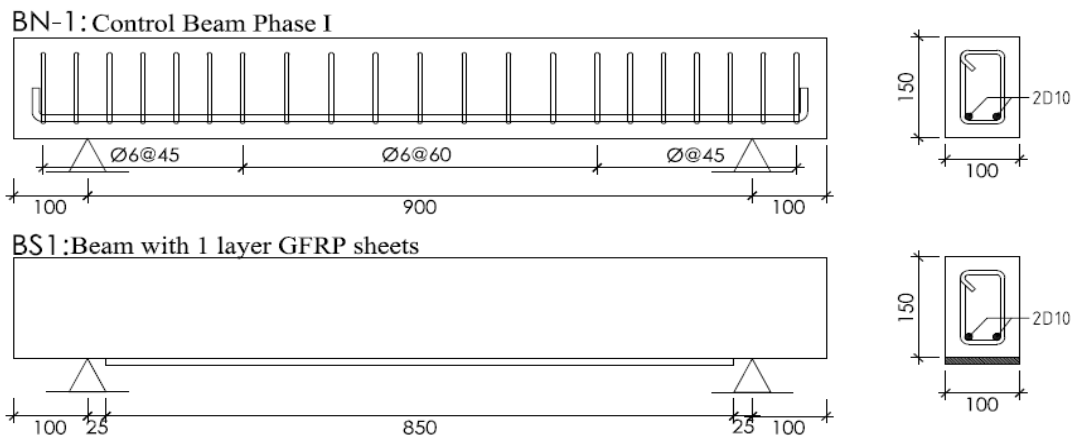

BS2:Beam with 2 layer GFRP sheets
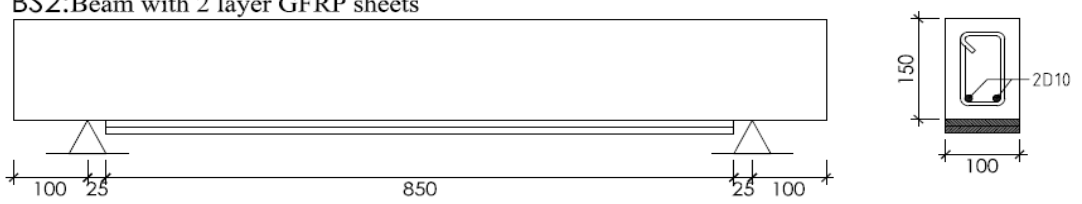

Fig. 1. Beam specimens in phase I. 
Three specimens were made for each variation, therefore, 24 beam specimens were tested. All specimens were moist cured by covering all beam surfaces with wet burlaps and plastic sheets for seven days. After curing time, the specimens were stored in a safe place at room temperature until the time of testing.
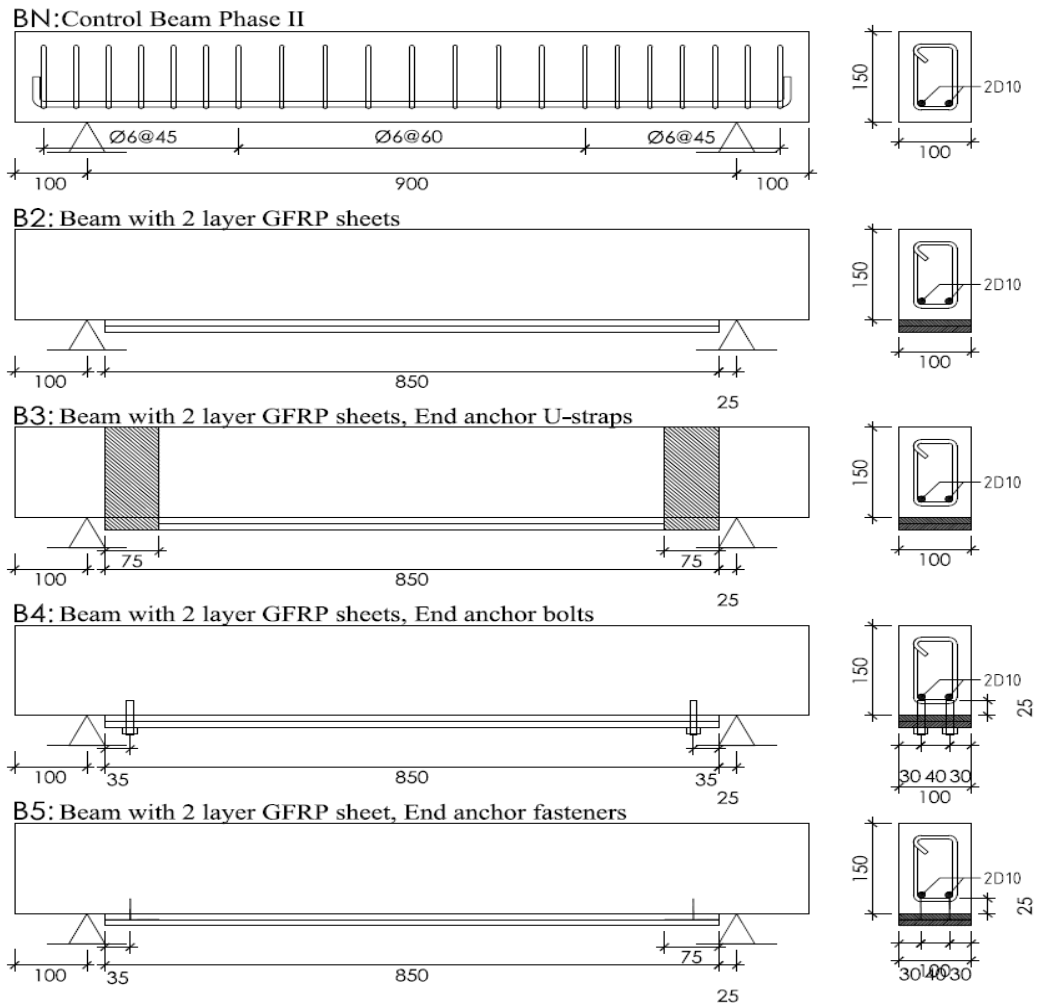

Fig. 2. Beam specimens in phase II.

\subsection{Test setup and instrumentations}

All specimens were tested after the concrete has aged for 28 days with four points loading setup as shown in Fig. 3. The beams were simply supported with load positions that were $300 \mathrm{~mm}$ from the supports. Two mechanical (or dial) gauges were used to measure midspan beams deflections during the test.

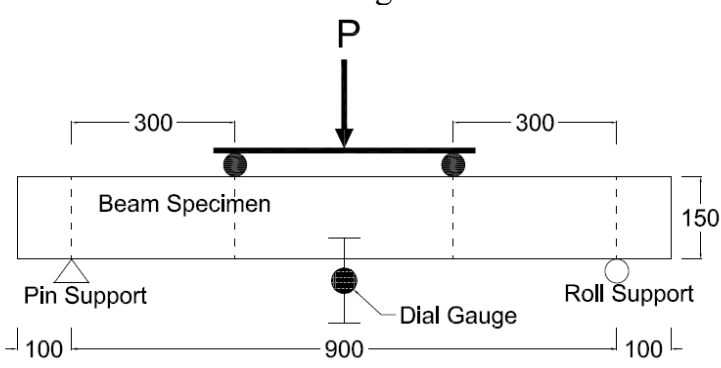

(a) Schematic test setup

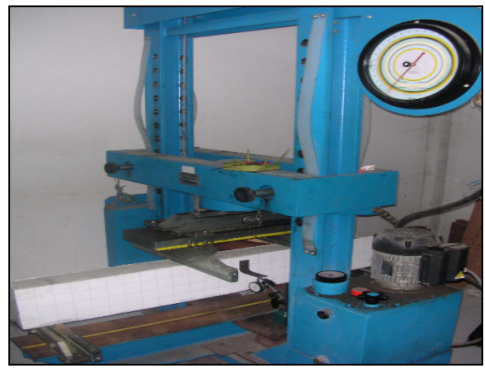

(b) Testing equipment

Fig. 3. Four points loading test setup (a) schematic test setup; (b) testing equipment. 


\section{Results and discussions}

\subsection{Mode of beam failure and capacities}

All beam specimens failed in flexure whether it was preceded by GFRP rupture or GFRP debonding. Local material of GFRP and epoxy can be effective only for one layer indicated by the fibre rupture. Increasing GFRP layers results in GFRP debonding at the concrete interface as shown in specimens BS2 and B2 of phase I and II respectively. The application of end anchors in phase II can improve significantly the performances of GFRP sheet. End anchor of GFRP using bolts enabled the two layers of GFRP sheet to develop their capacity indicated by fibre rupture. End anchors using GFRP U-straps and fasteners failed and then followed by GFRP debonding at higher capacity than the control specimen. It was also observed that the end anchors enabled changes in the location of initial GFRP delamination from the cut off end to the middle span.

Table 1. Failure modes and load capacity of all specimens.

\begin{tabular}{|c|c|c|c|c|}
\hline $\begin{array}{l}\text { Specimen } \\
\text { ID }\end{array}$ & Phase & Variations & $\begin{array}{c}\text { Ultimate } \\
\text { Loads (Pult) } \\
\text { kN }\end{array}$ & Failure Modes \\
\hline $\mathrm{BN1}$ & \multirow{9}{*}{ I } & \multirow{3}{*}{$\begin{array}{l}\text { Control specimen } \\
\text { Phase I }\end{array}$} & 52,5 & Flexure \\
\hline BN2 & & & 54,0 & Flexure \\
\hline BN3 & & & 55,0 & Flexure \\
\hline BS11 & & \multirow[t]{3}{*}{ One-layer GFRP } & 58,0 & Flexure, GFRP Rupture \\
\hline BS12 & & & 61,0 & Flexure, GFRP Rupture \\
\hline BS13 & & & 60,0 & Flexure, GFRP Rupture \\
\hline $\mathrm{BS} 21$ & & \multirow[t]{3}{*}{ Two layers GFRP } & 62,5 & Flexure, GFRP debonding \\
\hline BS22 & & & 60,5 & Flexure, GFRP debonding \\
\hline BS23 & & & 60,0 & Flexure, GFRP debonding \\
\hline BN1 & \multirow{15}{*}{ II } & \multirow{3}{*}{$\begin{array}{l}\text { Control specimen } \\
\text { Phase II } \\
\text { (w/o GFRP sheet) }\end{array}$} & 51.5 & Flexure \\
\hline BN2 & & & 50.0 & Flexure \\
\hline BN3 & & & 51.5 & Flexure \\
\hline $\mathrm{B} 21$ & & \multirow{3}{*}{$\begin{array}{l}\text { Two layers GFRP } \\
\text { (w/o end anchors) }\end{array}$} & 55.0 & Flexure, GFRP debonding \\
\hline $\mathrm{B} 22$ & & & 57.5 & Flexure, GFRP debonding \\
\hline $\mathrm{B} 23$ & & & 60.0 & Flexure, GFRP debonding \\
\hline B31 & & \multirow{3}{*}{$\begin{array}{l}\text { Two layers GFRP } \\
\text { with end anchor of } \\
\text { U-shape straps }\end{array}$} & 60.0 & $\begin{array}{l}\text { Flexure, Anchorage rupture, } \\
\text { GFRP debonding }\end{array}$ \\
\hline $\mathrm{B} 32$ & & & 60.0 & $\begin{array}{l}\text { Flexure, anchorage rupture, } \\
\text { GFRP debonding }\end{array}$ \\
\hline B33 & & & 61.0 & Flexure, GFRP rupture \\
\hline B41 & & \multirow{3}{*}{$\begin{array}{l}\text { Two layers GFRP } \\
\text { with end anchor of } \\
\text { bolts }\end{array}$} & 61.0 & Flexure, GFRP rupture \\
\hline B42 & & & 67.0 & Flexure, GFRP rupture \\
\hline B43 & & & 60.0 & Flexure, GFRP rupture \\
\hline B51 & & \multirow{3}{*}{$\begin{array}{l}\text { Two layers GFRP } \\
\text { with end anchor of } \\
\text { GFRP fasteners }\end{array}$} & 63.0 & Flexure, GFRP rupture \\
\hline B52 & & & 69.0 & $\begin{array}{l}\text { Flexure, Anchorage rupture, } \\
\text { GFRP debonding }\end{array}$ \\
\hline B53 & & & 69.0 & $\begin{array}{l}\text { Flexure, Anchorage rupture, } \\
\text { GFRP debonding }\end{array}$ \\
\hline
\end{tabular}

\subsection{Beam deflections}

Load-deformation behaviours of all specimens tested in phase I and II can be seen in Figures 4 and 5, respectively. It is shown that before the yielding of flexure reinforcement occurs, load-deflection curves of all specimens are similarly indicating that there is no 
significant improvement on beam stiffness in this stage. However, the local GFRP sheet bounded with local epoxy products to strengthen beams can improve the beam capacity. Once the GFRP failure occurs due to fibre rupture or debonding, all beams were back to the stage of yielding plateau to the capacity of control beam specimens. It occurred in all strengthened specimens both in phase I and II.
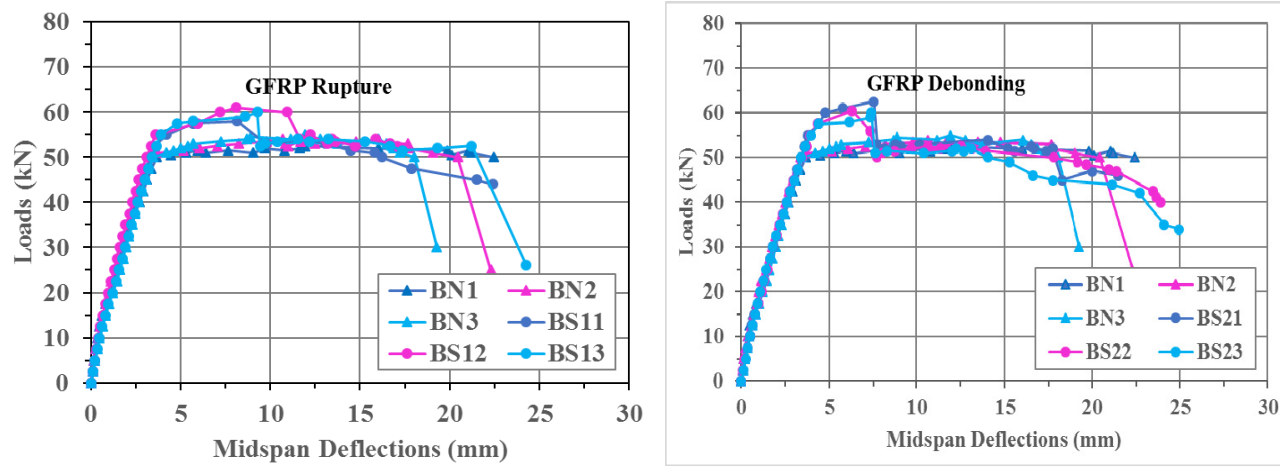

Fig. 4. Relationship between loads and midspan deflections of beams in Phase I.
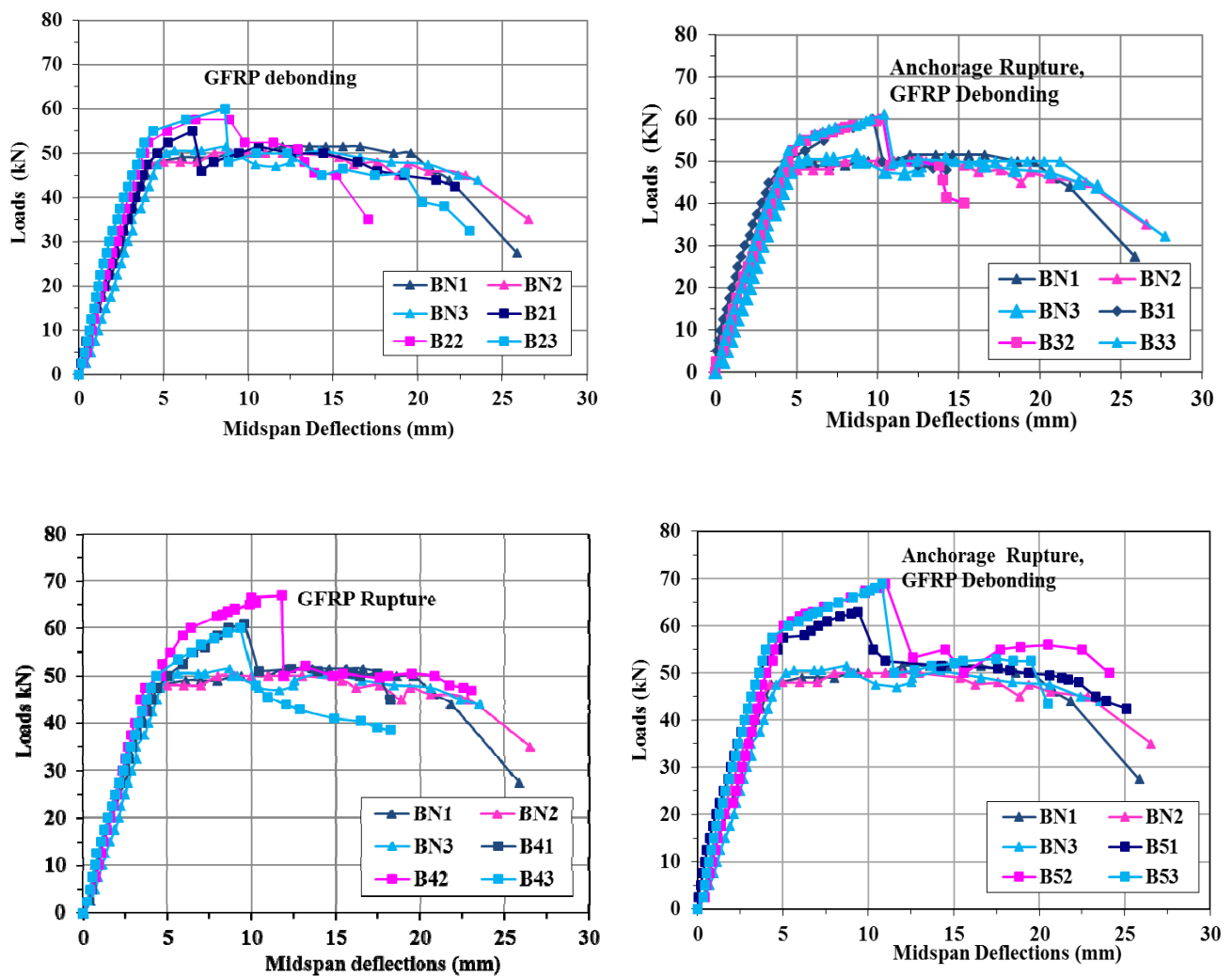

Fig. 5. Relationship between loads and midspan deflections of beams in Phase II. 


\subsection{Specimen capacities}

The local material GFRP sheet and epoxy can improve the flexural capacity of the beams as can be seen from Table 2. From the specimen in phase I, the flexural capacity of the beams can be increased by $10.8 \%$ and $13.4 \%$ from that of the control beam, respectively, for one and two layers. It was also obtained that applying end anchors at both ends of the GFRP sheets can further increase the beam capacities as shown from the specimens in phase II. The specimens with end anchors of GFRP fastener gave the highest capacities although it failed during the test (in B52 and B53). However, it was a gradual failure in which the GFRP sheet was able to develop greater strength. Similar results on FRP anchor or spike to overcome FRP debonding problem were also reported by [7].

Table 2. Beam flexure capacities.

\begin{tabular}{|c|c|c|c|c|}
\hline $\begin{array}{c}\text { Beam } \\
\text { ID }\end{array}$ & Phase & $\begin{array}{c}\text { Loads } \\
\text { (Pult) } \\
\text { kN }\end{array}$ & $\begin{array}{c}M_{\text {ult }} \\
(\mathbf{k N m})\end{array}$ & $\begin{array}{l}M_{\text {ult,avg }} \\
(\mathrm{kNm})\end{array}$ \\
\hline BN1 & \multirow{9}{*}{ I } & 52.5 & 7.88 & \multirow{3}{*}{8.08} \\
\hline BN2 & & 54.0 & 8.10 & \\
\hline $\mathrm{BN} 3$ & & 55.0 & 8.25 & \\
\hline BS11 & & 58.0 & 8.70 & \multirow{3}{*}{8.95} \\
\hline BS12 & & 61.0 & 9.15 & \\
\hline BS13 & & 60.0 & 9.00 & \\
\hline BS21 & & 62.5 & 9.38 & \multirow{3}{*}{9.15} \\
\hline BS22 & & 60.5 & 9.08 & \\
\hline BS23 & & 60.0 & 9.00 & \\
\hline
\end{tabular}

\begin{tabular}{|c|c|c|c|c|}
\hline $\begin{array}{c}\text { Beam } \\
\text { ID }\end{array}$ & Phase & $\begin{array}{c}\text { Loads } \\
\text { (Pult) } \\
\text { kN } \\
\end{array}$ & 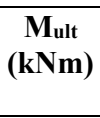 & $\begin{array}{l}\text { M }_{\text {ult,avg }} \\
(\mathbf{k N m})\end{array}$ \\
\hline BN1 & \multirow{15}{*}{ II } & 51.5 & 7.73 & \multirow{3}{*}{7.65} \\
\hline BN2 & & 50.0 & 7.50 & \\
\hline $\mathrm{BN} 3$ & & 51.5 & 7.73 & \\
\hline $\mathrm{B} 21$ & & 55.0 & 8.25 & \multirow{3}{*}{8.63} \\
\hline B22 & & 57.5 & 8.63 & \\
\hline B23 & & 60.0 & 9.00 & \\
\hline B31 & & 60.0 & 9.00 & \multirow{3}{*}{9.05} \\
\hline B32 & & 60.0 & 9.00 & \\
\hline B33 & & 61.0 & 9.15 & \\
\hline B41 & & 61.0 & 9.15 & \multirow{3}{*}{9.45} \\
\hline B42 & & 67.0 & 10.05 & \\
\hline B43 & & 60.0 & 9.00 & \\
\hline B51 & & 63.0 & 9.45 & \multirow{3}{*}{10.05} \\
\hline B52 & & 69.0 & 10.35 & \\
\hline B53 & & 69.0 & 10.35 & \\
\hline
\end{tabular}

\section{Conclusions}

The following conclusions can be drawn on the performances of local GFRP and Epoxy materials based on test results and discussions:

1. For the beams without end anchors, the full strength of GFRP can only be achieved in one-layer GFRP specimens. Up to two-layers GFRP sheets, the debonding failure occurred at the interface between concrete and epoxy results in GFRP delamination.

2. The beam flexural capacity can be increased by $10.8 \%$ and $13.4 \%$ of the control beams for one and two layers of GFRP sheet, respectively.

3. In the presence of end anchors performance of GFRP improved. End anchors changes the initial GFRP delamination from cut off end to the middle beam span.

4. The flexural capacity increased by $31.4 \%, 18.3 \%$ and $22.9 \%$ of the $2^{\text {nd }}$ phase control beams, respectively for fastener, U-strap and bolts anchor's types.

\section{References}

1. C. K. Y. Leung, Cement \& Conc. Composite. 28, 742-748 (2006)

2. F. Ceroni, Const and Build. Mat. 24(9), 1547-1559 (2010)

3. N. Attari, S. Amziane, and M. Chemrouk, Const \& Build. Mat. 37, 746-757 (2012) 
4. S. Tudjono, H. A. Lie, and B.S. Gan. Proc. Eng. 125, 1070-1075 (2015)

5. S. Tudjono, H. A. Lie, A. Hidayat, and Purwanto, Proc. Eng. 171, 1116-1122 (2017)

6. S. Tudjono, H. A. Lie, and B.S. Gan, Int. J. of Tech. 1, 5-15 (2018)

7. R. Kalfat and R. Al-Mahaidi, Comp. Str. 155, 89-98 (2016)

8. I. K. Sudarsana, A. A. Sutapa, J. Ilmiah T.Sipil, 11(1), 1-10 (2007)

9. P. Deskarta, J.Ilmiah T.Sipil, 13(2), 199-208 (2009)

10. I. M. A. Sudiasa, Final Project, PS.T.Sipil-Unud, (2003)

11. E. Artawa, Final Project, PS. T. Sipil-Unud, (2004) 